\title{
PERANCANGAN RENCANA STRATEGIS SISTEM INFORMASI DAN TEKNOLOGI INFORMASI (SI/TI): STUDI KASUS STMIK XYZ
}

\author{
Maryani; Suparto Darudiato \\ Jurusan Komputerisasi Akuntansi, Fakultas Ilmu Komputer, Bina Nusantara University \\ Jln. KH Syahdan No 9, Kemanggisan, Palmerah, Jakarta Barat 11480 \\ yanie@binus.edu; supartod@binus.edu
}

\begin{abstract}
Nowadays, business activity in every organization will not be parted from information system (IS) and information technology (IT). STMIK XYZ is one private college that has a good business growth. In order to reach the objective of the college in its vision and mission, it needs business strategy and IS/IT strategy. The basic concept in arranging framework IS/IT strategic planning in STMIK XYZ is John Ward and Joe Peppard's concept. The framework of IS/IT strategic planning consists of 5 steps, that are initialization preparation strategic planning of IS/IT, understanding business and information needs, defining target of IS/IT, defining strategic IS/IT, and planning and implementation. Strategic analysis uses PEST analysis method, BCG matrix analysis, five Porter power analysis, SWOT analysis, value chain analysis, CSF and KPI analysis. The research result is to make a framework of IS/IT integrated strategic planning so it could ease the management to manage resources to produce information that needed, accurate, and could be used by anybody.
\end{abstract}

Keywords: planning, business strategy, IS/IT strategy, information system strategic planning, Ward \& Peppard method.

\section{ABSTRAK}

Dewasa ini kegiatan bisnis suatu organisasi tidak terlepas dari peran Sistem informasi (SI) dan Teknologi Informasi (TI). STMIK XYZ adalah salah satu perguruan tinggi swasta yang saat ini mengalami pertumbuhan bisnis yang cukup baik. Dalam upaya mencapai tujuan STMIK XYZ yang terumuskan dalam visi dan misi, memerlukan strategis bisnis maupun strategis SI/TI. Konsep dasar yang digunakan dalam menyusun kerangka kerja Perencanaan Strategis SI/TI di STMIK XYZ konsep pemikiran John Ward dan Joe Peppard. Kerangka kerja Perencanaan Strategis SI/TI yang diusulkan terdiri dari 5 tahapan yaitu: inisialisasi persiapan perencanaan strategis SI/TI, memahami kebutuhan bisnis dan informasi, menentukan target SI/TI, menentukan strategis SI/TI, dan rencana dan implementasi. Analisis strategis menggunakan metode analisis PEST, analisis BCG matriks, analisis lima kekuatan Porter, analisis SWOT, analisis value chain, analisis CSF dan KPI. Hasil dari penelitian adalah membuat suatu kerangka kerja perencanaan strategi SI/TI yang terintegrasi sehingga memudahkan manajemen mengelola sumberdaya untuk menghasilkan informasi yang dibutuhkan, akurat, dapat digunakan secara bersama oleh semua pihak.

Kata kunci: perencanaan, strategi bisnis dan strategi SI/TI, perencanaan strategis sistem informasi, metodologi WardPeppard

\section{PENDAHULUAN}

Dijaman teknologi informasi yang pesat ini, kegiatan bisnis suatu organisasi tidak terlepas dari peran Sistem Informasi (SI) dan Teknologi Informasi (TI). SI merupakan sarana andalan guna memenangkan persaingan dalam industri, memudahkan organisasi dalam mewujudkan efesiensi proses back office, meningkatkan service quality kepada konsumen, membantu dalam pengambilan keputusan, perencanaan ke masa depan, memperluas pasar dan pemasaran produk. Melalui teknologi informasi perusahaan dapat memperoleh keunggulan strategis dalam persaingan antar pelaku bisnis yang ketat saat ini. Agar hal ini dapat tercapai diperlukan suatu perencanaan bisnis di bidang teknologi informasi. Sistem informasi berfungsi sebagai sarana dalam membantu organisasi untuk merealisasikan tujuan organisasi tersebut. Organisasi perlu melakukan penggalian kebutuhan bisnis dan mengevaluasi sumber daya Teknologi Informasi (TI) hingga diperoleh suatu peluang yang dapat dimanfaatkan dan dikembangkan oleh para pelaku yang terlibat dalam organisasi.
Bagi organisasi, memiliki strategis bisnis saja tidak cukup untuk menghadapi persaingan dewasa ini. Strategis bisnis yang biasa dituangkan dalam dokumen atau cetak biru Business Plan harus pula dilengkapi dengan strategi SI/ TI. Tujuannya jelas, yaitu memanfaatkan secara optimum penggunaan teknologi informasi sebagai komponen utama sistem informasi organisasi perusahaan. Mengapa strategi SI/TI perlu dibuat? Pertama adalah karena sumber daya yang dimiliki perusahaan sangat terbatas, sehingga harus digunakan seoptimal mungkin. Kedua untuk meningkatkan daya saing atau kinerja perusahaan, karena para kompetitor memiliki sumber daya teknologi yang sama. Alasan ketiga adalah untuk memastikan bahwa asset teknologi informasi dapat dimanfaatkan secara langsung maupun tidak langsung meningkatkan profitabilitas perusahaan, baik berupa peningkatan pendapatan atau revenue maupun pengurangan biaya-biaya atau cost. Keempat adalah untuk mencegah terjadinya kelebihan investasi (over investment) atau kekurangan investasi (under investmen) di bidang teknologi informasi. Dengan demikian diperlukan suatu perencanaan 
startegi SI/TI yang benar-benar menjawab kebutuhan bisnis organisasi akan informasi.

STMIK XYZ adalah salah satu perguruan tinggi swasta yang saat ini sedang dalam masa pertumbuhan bisnis yang cukup baik. Dalam mencapai tujuan STMIK XYZ yang terumus dalam visi dan misi, memerlukan strategi bisnis maupun strategi SI/TI. Untuk memenangkan persaingan dalam kompetisi saat ini. STMIK XYZ merancang rencana strategis SI/TI yang selaras dengan strategi bisnis. Sistem informasi yang digunakan saat ini hanya ada di tiga bidang utama yaitu bidang akademik, bidang administrasi umum dan keuangan, serta bidang administrasi kemahasiswaan. Sistem informasi tersebut saat ini berjalan dengan modul yang terpisah dan tanpa disertai dengan perencanaan matang mengenai arahan visi dan misi sistem informasinya.

Ada beberapa konsep pemikiran perencanaan strategi $\mathrm{SI} / \mathrm{TI}$ yang sering diacu selama ini antara lain yang dinyatakan oleh Ward and Preppard, Turban, James Martin dan Tozer. Terdiri atas metode-metode yang diurutkan secara logis dan memiliki kelebihan satu dengan yang lainnya. Konsep pemikiran perencanaan strategi SI/TI yang digunakan dalam pengembangan SI/TI untuk merancang sebuah sistem informasi strategi yang sesuai dengan kebutuhan STMIK XYZ dalam penelitian ini, menggunakan konsep pemikiran Ward and Preppard. Yang nantinya dijadikan dasar dalam membangun kerangka kerja perencanaan strategis SI/TI STMIK XYZ.

YayasanKristenWiduriuntukPendidikanPembangunan Sosial (YKW-PPS) telah bergerak dalam bidang Pendidikan Tinggi, kemudia tahun 1992 menjadi STMIK XYZ. Sekolah Tinggi Manajemen Informatika \& Komputer saat ini memiliki tiga jurusan yaitu Sistem Informasi (S1), Teknik Informatika (S1), Manajemen Informatika (D3). Dengan visinya menjadi perguruan tinggi yang terkemuka di DKI Jakarta dalam penguasaan ilmu pengetahuan dan teknologi informasi, visi memberikan pendidikan, pengajaran, penelitian dan pelatihan (keterampilan ) kepada mahasiswa untuk mengembangkan dirinya menjadi tenaga ahli yang berkarakter, berjiwa pemimpin, profesional dalam bidang teknologi informasi, serta mempunyai semangat wirausaha.

Permasalahan dalam penulisan Penelitian ini adalah bagaimana membuat suatu perencanaan strategis SI yang sesuai dengan strategi organisasi sehingga bisa mendukung kinerja organisasi secara kontinyu, agar apa yang dilakukan pada pengembangan SI/TI dapat terus berkesinambungan dan mempunyai arahan yang jelas serta sesuai dengan rencana strategis dari organisasi. Menurut pengamatan peneliti selama ini masih ada organisasi yang masih menggunakan sistem informasi sebagai hanya pendukung kerja operasional organisasi tanpa disertai perencanaan matang mengenai arahan visi dan misi sistem informasinya. Untuk itulah maka penulis mencoba mengangkat permasalahan yaitu perencanaan strategis sistem informasi, dengan studi kasus pada STMIK XYZ.

Hal ini diperlukan karena hingga saat ini STMIK XYZ belum mempunyai suatu perencanaan SI/TI yang jelas namun ada kinginan dari pihak pemilik organisasi untuk memanfaatkan kelebihan SI/TI, sehingga pengembangan SI/ TI yang akan dilakukan oleh organisasi sering menghadapi banyak kendala utama dalam menentukan prioritasnya. Sejalan dengan perubahan kebijakan-kebijakan organisasi yang diikuti pula perubahaan peran dan fungsi sistem informasi, maka permasalahan yang timbul yaitu (1) belum mempunyai perencanaan strategi SI/TI yang baik untuk mendukung strategi bersaing dengan perguruan tinggi lainnya; (2) sarana dan prasarana komputer yang belum termanfaatkan secara optimal karena belum adanya arahan yang jelas; (3) keterbatasan sumberdaya yang dimiliki perusahaan dalam mendukung kinerja organisasi.

Hal-hal diatas timbul karena belum adanya suatu perencanaan strategis sistem informasi dan teknologi informasi STMIK XYZ yang terpadu, yang memberikan arahan yang jelas dalam mendukung visi, misi organisasi
Berdasarkan latar belakang dan kondisi SI/TI dari organisasi, maka permasalahan yang akan dibahas dalam penelitian ini adalah bagaimana menyusun suatu usulan perencanaan strategik sistem informasi dan teknologi informasi dari STMIK XYZ sehingga peranan SI/TI dapat lebih optimal dalam mendukung kinerja organisasi.

Tujuan yang akan diperoleh dari penelitian ini adalah untuk menghasilkan suatu bentuk usulan perencanaan strategi SI/TI STMIK XYZ agar dapat mendukung strategi bersaing dengan perguruan tinggi lainnya, serta dapat mendukung terwujudnya visi dan misi dari organisasi.

Manfaat yang dihasilkan dari kerangka kerja perencanaan strategi SI/TI adalah: (1) menselaraskan perencanaan SI/TI dengan perencanaan strategis di STMIK XYZ; (2) mengetahui kelebihan dan kekurangan dari sistem yang terdapat pada STMIK XYZ, terutama bidang pendidikan dan pengajaran; (3) menghasilkan perencanaan strategi informasi bagi perusahaan untuk tiga tahun mendatang, yang dapat dipakai untuk pedoman dalam pengembangan SI/TI; (4) mempunyai keunggulan kompetitif dalam bidang teknologi informasi dan sistem informasi untuk STMIK XYZ. Dengan demikian akan bisa meningkatkan kemampuan bersaing dalam organisasi sejenis lainnya dengan memanfaatkan implementasi perencanaan SI/TI tersebut.

Agar penelitian ini dapat tercapai sesuai dengan tujuan penelitian, maka ditetapkan beberapa batasan masalah antara lain: (1) menyusun kerangka kerja perencanaan strategi SI/TI berdasarkan metodologi perencanaan strategi sistem informasi oleh Ward \& Peppard (2002); ruang lingkup dari interprestasi kerangka kerja perencanaan strategi SI/TI STMIK XYZ dibatasi pada bagian pendidikan yang merupakan bisnis inti dari STMIK XYZ dengan bagian pendukung sumber daya, keuangan dan logistik; (3) identifikasi dengan mengkaji dan mereview kajian lingkungan, situasi dan strategi organisasi, review-review tersebut dibutuhkan untuk menentukan kebutuhan SI/TI kedepan sehingga ada keselarasan antara bisnis dan penggunaan SI/TI; (4) me-review kondisi organisasi IT STMIK XYZ saat ini termasuk visi, misi dan strategi, serta situasi perkembangan SI/TI dengan melakukan identifikasi dan pemetaan terhadap sistem informasi, infrastruktur teknologi informasi dan komunikasi teknologi, serta struktur organisasi; (5) melakukan analisis kebutuhan SI/TI untuk mencapai tujuan strategis. Selain itu dilakukan pula analisis kesenjangan antara kondisi tersebut dengan kondisi SI/TI saat ini.

\section{Kajian Teori}

\section{Strategi SI dan Strategi TI}

Agar penerapan TI optimal, dibutuhkan suatu strategi SI/TI yang selaras dengan strategi bisnis organisasi. Hal ini diperlukan agar investasi yang dikeluarkan untuk TI sesuai dengan kebutuhan dan memberi manfaat yang diukur dari pencapaian tujuan dan sasaran organisasi.

Earl membedakan antara strategi SI dan TI (Earl, 1996). Strategi SI menekankan pada penentuan aplikasi sistem informasi yang dibutuhkan rganisasi. Esensi dari strategi SI adalah menjawab pertanyaan apa. Sedangkan strategi TI lebih menekankan pada pemilihan teknologi, infrastruktur, dan keahlian khusus yang terkait atau menjawab pertanyaan bagaimana. Sebagai contoh suatu organisasi menerapkan Executive Information System pada bidang pemasaran hal ini mempengaruhi aliran informasi vertikal dalam perusahaan. Pihak manajemen atas memiliki akses informasi yang lebih besar dan mengurangi ketergantungan sumber informasi terhadap manajemen menengah. Jaringan telekomunikasi sebagai aplikasi teknologi informasi memungkinkan informasi mengalir dengan mudah dan cepat di antara departemen dan divisi yang berbeda. Hubungan antara strategi TI, strategi SI dan strategi bisnis terlihat pada Gambar 1 di bawah ini: 


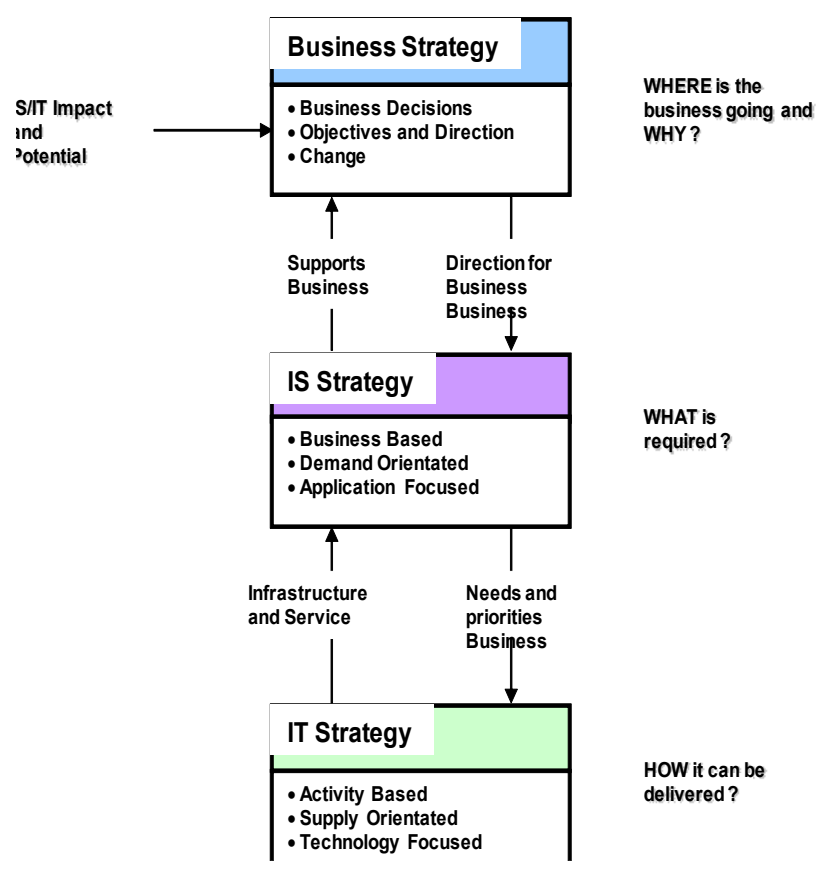

Gambar 1 Hubungan antara Strategi Bisnis, Strategi SI, dan Strategi TI (Ward \& Peppard, 2002)

Untuk menentukan strategi SI/TI yang dapat mendukung pencapaian visi dan misi organisasi, maka perlu pemahaman tentang strategi bisnis organisasi. Pemahaman tersebut mencakup penjelasan terhadap hal-hal berikut : mengapa suatu bisnis dijalankan, kemana tujuan, dan arah bisnis, kapan tujuan tersebut dicapai, bagaimana cara mencapai tujuan dan adakah perubahan yang harus dilakukan. Jadi dalam membangun suatu strategi SI/TI, yang menjadi isu sentral adalah penyelarasan (alignment) strategi SI/TI dengan strategi bisnis organisasi.

\section{Perencanaan Strategis SI/TI}

Perencanaan strategis SI/TI merupakan proses identifikasi portofolio aplikasi SI berbasis komputer yang akan mendukung organisasi dalam pelaksanaan rencana bisnis dan Merealisasikan tujuan bisnisnya. Perencanaan strategis SI/TI mempelajari pengaruh SI/TI terhadap kinerja bisnis dan kontribusi bagi organisasi dalam memilih langkahlangkah strategis. Selain itu, perencanaan strategis SI/TI juga menjelaskan berbagai tools, teknik, dan kerangka kerja bagi manajemen untuk menyelaraskan strategi SI/TI dengan strategi bisnis, bahkan mencari kesempatan baru melalui penerapan teknologi yang inovatif (Ward \& Peppard, 2002). Gambar 2 menunjukkan skema perencanaan strategis SI/TI Ward dan Peppard.

Beberapa karakteristik dari perencanaan strategis SI/ TI antara lain adalah adanya misi utama, yaitu keunggulan strategis atau kompetitif dan kaitannya dengan strategi bisnis; adanya arahan dari eksekutif atau manajemen senior dan pengguna; serta pendekatan utama berupa inovasi pengguna dan kombinasi pengembangan bottom up dan analisa top down (Pant \& Hsu, 1995).

\section{Metodologi Perencanaan Strategis SI/TI Versi Ward \&Peppard}

Faktor penting dalam proses perencanaan strategis SI/ TI adalah penggunaan metodologi. Metodologi merupakan kumpulan dari metode, teknik, dan tools yang digunakan untuk mengerjakan sesuatu. Tujuan dari penggunaan metodologi dalam perencanaan strategis SI/TI adalah untuk meminimalkan resiko kegagalan, memastikan keterlibatan semua pihak yang berkepentingan serta meminimalkan ketergantungan individu, dan lebih menekankan kepada proses dan sasaran yang ditentukan. Pendekatan metodologi versi Ward and Peppard ini dimulai dari kondisi investasi SI/ TI dimasa lalu yang kurang bermanfaat bagi tujuan bisnis organisasi dan menangkap peluang bisnis, serta fenomena meningkatkan keunggulan kompetitif suatu organisasi karena mampu memanfaatkan SI/TI dengan maksimal. Kurang bermanfaatnya investasi SI/TI bagi organisasi disebabkan karena perencanaan strategis SI/TI yang lebih fokus ke teknologi, bukan berdasarkan kebutuhan bisnis.

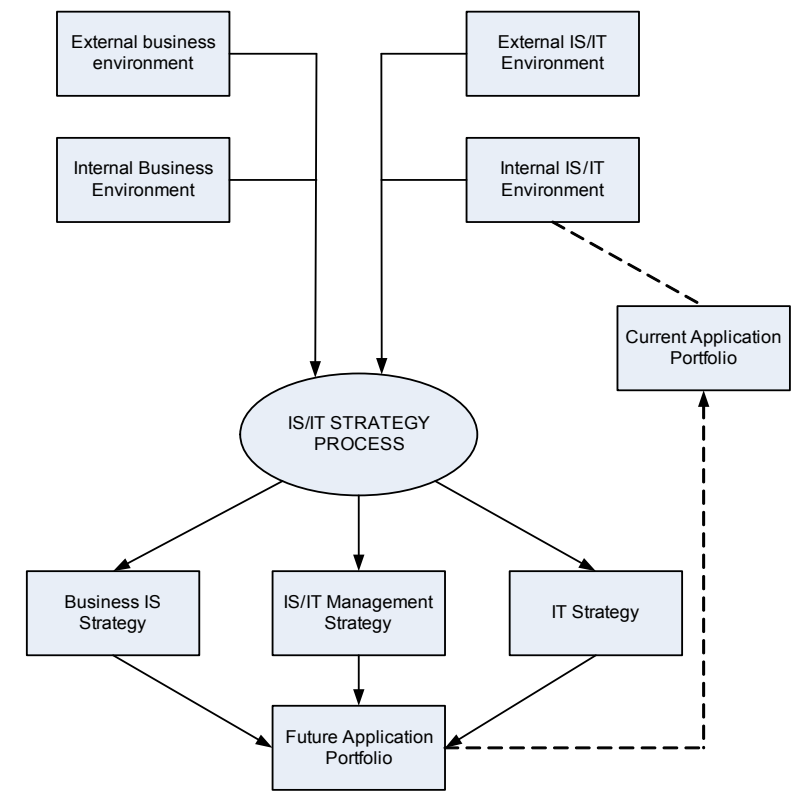

Gambar 2 Model Strategis SI/TI (Ward \& Peppard 2002)

Metodologi versi ini terdiri dari tahapan masukan dan tahapan keluaran (Ward \& Peppard, 2002). Tahapan masukan terdiri dari: (1) analisis lingkungan bisnis internal, yang mencakup aspek-aspek strategi bisnis saat ini, sasaran, sumber daya, proses, serta budaya nilai-nilai bisnis organisasi; (2) analisis lingkungan bisnis eksternal, yang mencakup aspekaspek ekonomi, industri, dan iklim bersaing perusahaan; (3) analisis lingkungan SI/TI internal, yang mencakup kondisi SI/TI organisasi dari perspektif bisnis saat ini, bagaimana kematangannya (maturity), bagaimana kontribusi terhadap bisnis, keterampilan sumber daya manusia, sumber daya dan infrastruktur teknologi, termasuk juga bagaimana portofolio dari SI/TI yang ada saat ini; (4) analisis lingkungan SI/ TI eksternal, yang mencakup tren teknologi dan peluang pemanfaatannya, serta penggunaan SI/TI oleh kompetitor, pelanggan dan pemasok. Sedangkan tahapan keluaran merupakan bagian yang dilakukan untuk menghasilkan suatu dokumen perencanaan strategis SI/TI yang isinya terdiri dari: strategi SI bisnis, yang mencakup bagaimana setiap unit/fungsi bisnis akan memanfaatkan SI/TI untuk mencapai sasaran bisnisnya, portofolio aplikasi dan gambaran arsitektur informasi, strategi TI, yang mencakup kebijakan dan strategi bagi pengelolaan teknologi dan sumber daya manusia SI/ TI, dan strategi Manajemen SI/TI, yang mencakup elemenelemen umum yang diterapkan melalui organisasi, untuk memastikan konsistensi penerapan kebijakan SI/TI yang dibutuhkan.

\section{Metode dan Teori Analisis Perencanaan Strategis SI/TI}

Beberapa teknik/metode analisis yang digunakan 
dalam perencanaan strategis SI/TI pada metodologi ini, mencakup analisis PEST, SWOT, analisis Five Forces Competitive, analisis Value Chain, metode Critical Succes Factors, dan McFarlan's Strategic Grid.

\section{Analisis PEST}

P.E.S.T adalah singkatan dari Politik, Ekonomi, Sosial dan Teknologi. Analisis ini digunakan untuk mengindentifikasi kondisi lingkungan umum atau lingkungan makro organisasi/ perusahaan. Identifikasi ini berdasarkan aspek politik dan hukum. Aspek ekonomi, aspek sosial dan budaya, serta aspek teknologi.

\section{Analisis SWOT}

Analisis SWOT akan dipetakan dari hasil analisis lingkungan. Kekuatan diidentifikasikan dengan tujuan untuk mengetahui apa saja kekuatan organisasi untuk dapat meneruskan dan mempertahankan bisnis. Dengan mengetahui kekuatan yang dimiliki organisasi akan dapat mempertahankan dan bahkan meningkatkan kekuatan sebagai modal untuk dapat bersaing. Mengidentifikasi kelemahan bertujuan untuk dapat mengetahui apa kelemahan-kelemahan yang masih ada, dan dengan mengetahui kelemahan tersebut, maka perusahaan dapat berusaha untuk memperbaiki agar menjadi lebih baik. Kelemahan yang tidak atau terlambat teridentifikasi akan merugikan bagi perusahaan. Oleh karena itu dengan semakin cepat mengetahui kelemahan, maka perusahaan juga dapat sesegera mungkin mencari solusi untuk dapat menutupi kelemahan tersebut. Dengan mengetahui peluang, baik peluang saat ini maupun peluang dimasa yang akan datang, maka perusahaan dapat mempersiapkan diri untuk dapat mencapai peluang tersebut. Berbagai strategi dapat disiapkan lebih dini dan terencana dengan lebih baik sehingga peluang yang telah diidentifikasi dapat direalisasikan. Berbagai jalan untuk dapat mewujudkan peluang/kesempatan dan mempertahankan kelangsungan bisnis organisasi tentunya akan mengalami banyak ancaman. Ancaman yang dapat teridentifikasi dapat dicarikan jalan keluarnya sehingga organisasi dapat meminimalkan ancaman tersebut.

\section{Five Forces Competitive}

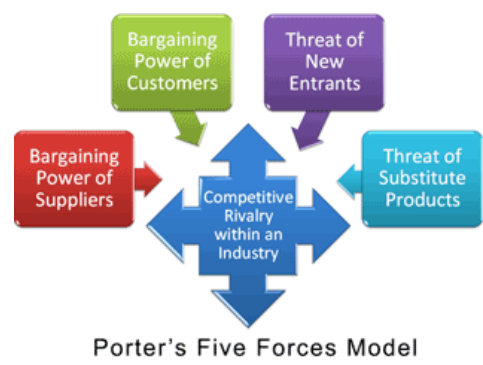

Gambar 3 Five Forces Model

Analisis kompetitif digunakan untuk mengevaluasi struktur lingkungan bisnis suatu industri dan tantangan dari pesaing dalam suatu industri. Hasil diagram kompetitif model suatu organisasi digunakan sebagai dasar untuk mengindentifikasi peluang dari eksternal organisasi guna pemanfaatan SI dan TI yang dapat menigkatkan keunggulan kompetitif bisnisnya. Porter (1985) membagi kekuatan industri menjadi 5 bagian, yaitu: (1) daya tawar konsumen (bargaining power of buyer), berasal dari konsumen produk/jasa dalam industri. Suatu perusahaan perlu mempertimbangkan, mengetahui pengaruh, manfaat dan keadaan daya tawar tersebut; (2) daya tawar pemasok (bargaining power of supplier), berasal dari penyediaan produk/jasa yang turut berkontribusi pada keunggulan kompetitif suatu perusahaan disuatu industri. Daya tawar pemasok akan kuat apbila pemasok memilki pasaokan terhadap produk yang unik/jarang ditemukan. Pemaso tersebut perlu memotivasi agar terus menerus melakukan kerjasama dengan suatu organisasi, begitu pula sebaliknya; (3) tekanan dari pendatang baru (threats of new entrance), pendatang baru yang akan ikut serta berkompetisi didalam perusahaan baru, perusahaan lama berstrategi bisnis yang berbeda untuk masuk ke pasar yang baru, perusahaan lama yang tadinya tidak berkompetisi pada area yang sama kini berpindah ke area yang sama dengan perusahaan kita. Tekanan tersebut disikapi perusahaan yang sudah ada dengan meninggikan Entry Barrier, Entry Barries tersebut dapat berupa Entry cost/Switching cost bagi konsumen yang tinggi, keluar dari persaingan, dan berhenti dari bisnis; (4) tekanan dari produk pengganti (threat of substitute product), tantangan ini berasal dari produk/jasa alternatif lain yang ditawarkan perusahaan dalam suatu industri. Produk/jasa alternatif tersebut perlu mempertimbangkan alasan ketertarikan dan pilihan konsumen; (5) rivalitias intra industri (intra industri rivalry), rivalitas yang terjadi berupa kompetisi diantara perusahaan dalam suatu industri yang sama.

\section{Critical Success Factor (CSF)}

Analisa CSF merupakan suatu ketentuan dari organisasi dan lingkungannya yang berpengaruh pada keberhasilan atau kegagalan. $C S F$ dapat ditentukan jika objektif organisasi telah diidentifikasi. Tujuan dari CSF adalah menginterpretasikan objektif secara lebih jelas untuk menentukan aktivitas yang harus dilakukan dan informasi apa yang dibutuhkan. Peranan $C S F$ dalam perencanaan strategis adalah sebagai penghubung antara strategi bisnis organisasi dengan strategi SI-nya, memfokuskan proses perencanaan strategis SI pada area yang strategis, memprioritaskan usulan aplikasi SI dan mengevaluasi strategi SI, seperti terlihat pada gambar dibawah ini.

\section{McFarlan Strategic Grid}

McFarlan strategic grid digunakan untuk memetakan aplikasi SI berdasarkan konstribusinya terhadap organisasi. Pemetaan dilakukan pada empat kuadran (strategic, high potential, key operation, and support). Dari hasil pemetaan tersebut didapat gambaran konstribusi sebuah aplikasi SI terhadap organisasi dan pengembangan dimasa mendatang (Ward \& Griffith, 1996) keempat kuadran tersebut dapat dilihat pada Gambar 4.

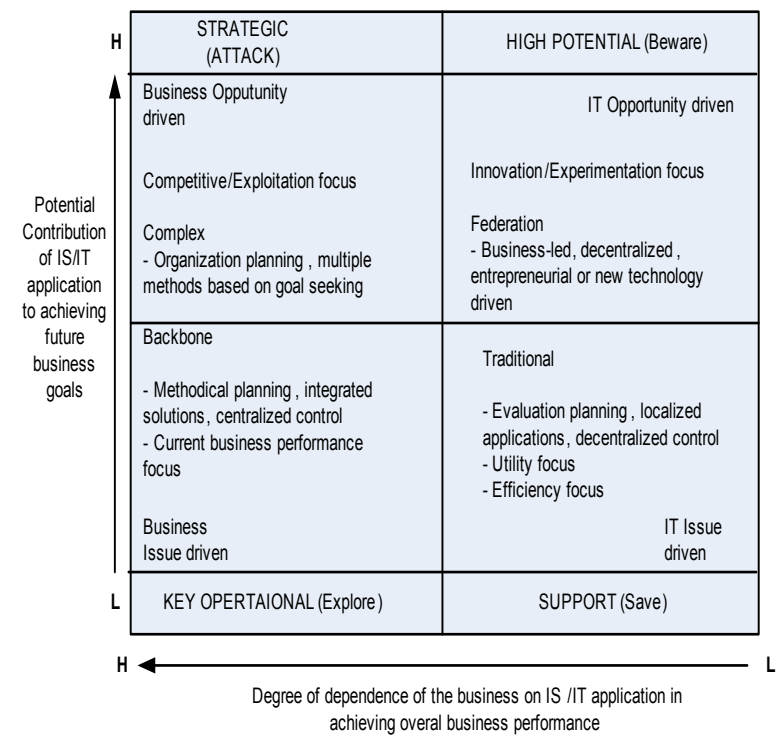

Gambar 4 McFarlan Strategic Grid (Ward and Peppard, 2002) 


\section{Analisis Value Chain}

Analisa Value Chain dilakukan untuk memetakan seluruh proses kerja yang terjadi dalam organisasi menjadi dua kategori aktivitas, yaitu aktivitas utama dan aktivitas pendukung. Mengacu pada dokumen organisasi yang menyebutkan tugas dan fungsi setiap unit kerja berdasarkan pengamatan yang dilakukan terhadap proses kerja yang terjadi di masing-masing unit kerja, secara diagram value chain dapat terlihat seperti gambar dibawah ini.

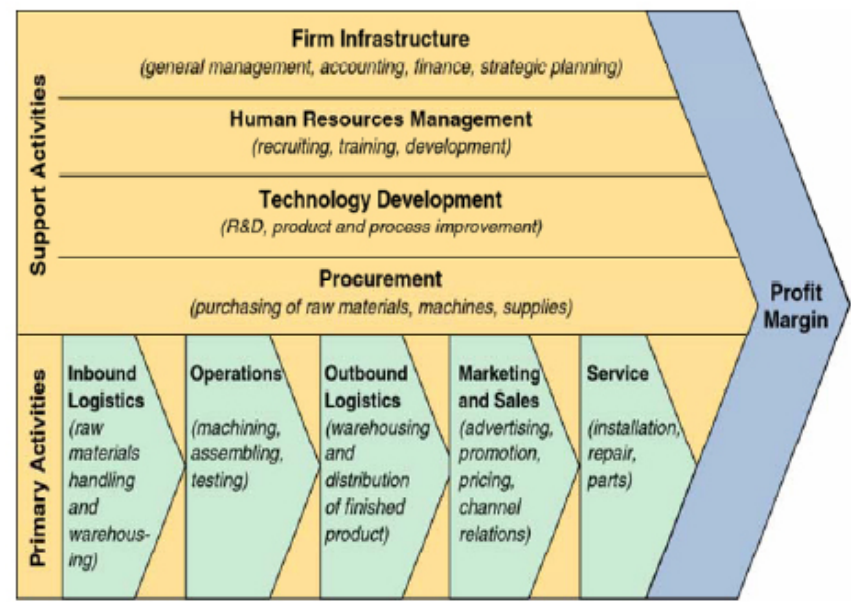

Gambar 5. Diagram Value Chain (Ward and Peppard 2002)

\section{PEMBAHASAN}

\section{Kerangka Kerja Perencanaan Strategi SI/ TI STMIK XYZ}

Penelitian dimulai dari analisis dan perumusan masalah di STMIK XYZ, kemudian melakukan pengumpulan data dengan penyebaran kuesioner dan wawancara yang berisikan pertanyaan yang diajukan kepada responden untuk mengumpulkan informasi mengenai sistem informasi dan teknologi informasi di STMIK XYZ. Kemudian dilakukan perumusan strategi SI/TI dengan konsep dasar pemikiran Ward and Preppard.

\section{Tahap 1: Mempersiapkan Perencanaan Strategi SI/TI}

Kegiatan ini bertujuan menginisialisasi perencanaan strategi SI/TI. Hal-hal yang harus dipersiapkan adalah (1) Menetapkan tujuan, sasaran, ruang lingkup perencanaan strategi SI/TI; (2) Metodologi atau pendekatan yang digunakan dalam perencanaan strategi SI/TI; (3) identifikasi partisipan-partisipan bisnis yang diperlukan selama proses, tim dibentuk selama proses, tim dibentuk dan dilatih; (4) mekanisme manajemen dan pengarahan dibuat; (5) bagaimana hasil kerja dihubungkan dengan perencanaan bisnis; (6) perencanaan kerja, waktu, tugas, peran dan tanggung jawab. Hal yang terpenting dalam perencanaan strategi, yaitu adanya komitmen dan dukungan dari top management.

\section{Tahap 2: Memahami Kebutuhan Bisnis Organisasi dan Informasi}

Tujuan dari tahap ini untuk menghasilkan informasi yang menggambarkan keadaan bisnis dan SI/TI terkini organisasi, kebutuhan bisnis mendatang, dan peluang pemanfaatan SI/TI dalam bisnis. Agar kegiatan tersebut dapat dilakukan dengan baik maka diperlukan masukan dari rencana bisnis, rencana SI/TI, keadaan persaingan di dalam bisnis dan perkembangan SI/TI dalam bisnis. Untuk mencapai tujuan kegiatan tersebut diperlukan beberapa proses antara lain: identifikasi informasi organisasi, analisis lingkungan eksternal bisnis organisasi, analisis lingkungan internal bisnis organisasi, dan analisis lingkungan eksternal SI/TI organisasi. Proses tersebut akan dijelaskan pada sub bab berikut ini:

\section{Identifikasi Informasi Organisasi}

Identidikasi informasi organisasi dapat dilakukan dengan memperoleh misi, visi. Objektif dan tujuan organisasi, identiifikasi faktor kunci keberhasilan (critical success faktor, $\mathrm{CSF})$, dan memperoleh gambaran global struktur organisasi.

\section{Menentukan visi, misi, organisasi}

Dalam suatu organisasi, selalu mempunyai visi dan misi. Misi adalah tujuan atau penyebab mengapa suatu organisasi didirikan. Rumusan misi yang baik akan menggambarkan secara jelas tujuan dasar, sehingga dapat dibedakan dengan organisasi yang lain dalam arti keunikan produk yang dihasilkan dan pasar yang dituju. Sedangkan visi atau pandangan ke depan organisasi menyangkut bentuk, keadaan atau wujud organisasi.

\section{Menentukan Objektif, Tujuan Organisasi}

Objektif adalah hasil suatu aktifitas yang diharapkan dapat dicapai dalam waktu tertentu. Objektif sedapat mungkin dinyatakan secara kuantitatif agar mudah diukur. Objektif harus merupakan hasil yang sesuai dengan misi organisasi. Perlu membedakan tujuan (goal) dan objektif (objective) yang kelihatannya sama, tetapi sebetulnya sangat beda. Tujuan adalah hal yang ingin dicapai dalam waktu yang tidak ditentukan. Sehingga semacam cita-cita dalam jangka panjang, sedangkan objektif adalah hal-hal yang direncanakan dicapai dalam jumlah tertentu dan waktu tertentu.

\section{Identifikasi CSF (Critical Success Factor) Organisasi}

Pada sutu organisasi, paling tidak ada dua alasan mengapa sebuah faktor dianggap sangat penting atau sangat kritis, yaitu: (1) memungkinkan untuk dijadikan faktor keuggulan bersaing (competitive advantage). Sebuah faktor internal dapat dipilih menjadi CSF karena sangat penting bagi pencipta keunggulan bersaing bagi organisasi (perguruan tinggi) maupun pesaing; (2) menjadi persyaratan bisnis pokok (Basic business requiriment). Sebuah faktor internal dipilih menjadi CSF karena sangat penting, yaitu keberadaannya menjadi syarat minimal agar organisasi dapat tetap terus beroperasi.

Rumusan CSF sebaiknya tidak hanya didasarkan pada kondisi eksisting tetapi juga harus mempertimbangkan perubahan-perubahan lingkungan dimasa depan sebab CSF sangat ini mungkin saja berbeda dengan CSF di masa depan, karena lingkungan telah berubah. Oleh sebab itu CSF sebaiknya diperiksa kembali setelah didentifikasi isu-isu lingkungan yang strategis. Isu-isu tersebut tidak menutup kemungkinan bakal berubah CSF suatu perguruan tinggi, dan hendaknya team perumus CSF terdiri dari orang-orang yang sangat memahami bisnis eksisting dan perkembangan perubahan lingkungan dimasa depan sehingga walaupun tanpa analisis situasi yang formal masih dapat diperoleh CSF yang akurat. Untuk menentukan CSF dapat digunakan alat Bantu untuk menggali ide agar terindentifikasi CSF secara akutat yaitu: Membuat Daftar Internal Kunci - Fungsional, infotmasi tentang sejarah pertumbuhan STMIK XYZ, dan menggunakan Value Chain sebagai cara memandang secara sistematis serangkaian kegiatan yang dilakukan organisasi untuk memuaskan pelanggan yang dilayaninya. 


\section{Analisis Lingkungan Eksternal Bisnis Organisasi}

Analisis lingkungan eksternal bisnis berfungsi untuk mengenali kondisi eksternal organisasi dan mengetahui posisi serta daya saing organisasi terhadap pesaing. Selain itu juga dapat digunakan untuk mencari peluang guna keunggulan kompetensi organisasi untuk pembentukan strategi bisnis yang mutakhir atau evaluasi kondisi dan strategi saat ini.

Adapun kegiatan dalam mengidentifikasi lingkungan eksternal adalah: (1) mengidentifikasi faktor-faktor yang mempengaruhi organisasi dari beberapa aspek yaitu Politik, Hukum, Ekonomi, Sosial, Ekologi dan Teknologi.
Untuk mengidentifikasi faktor-faktor tersebut diatas dapat menggunakan Analisis PEST. Analisis PEST mempunyai kemampuan dalam mengenali dan mengevaluasi peluang dan ancaman eksternal, sehingga organisasi akan mampu mengembangkan visi dan misi sebagai dasar strategi yang tepat untuk mencapai sasaran jangka panjang. (2) Mengidentifikasi posisi organisasi terhadap pesaing dengan menggunakan Analisis BCG Matriks di mana masing-masing unit bisnis dipetakan menurut tingkat pertumbuhan pasar dan posisi bersaing relatif. (3) Setelah menempatkan berbagai bisnisnya ke matrik BCG organisasi harus memutuskan apakah portofolio bisnisnya sehat apa tidak. Portofolio yang 
tidak seimbang adalah yang terlalu banyak mempunyai anjing (dog) atau tanda tanya (question mark) dan/atau terlalu sedikit bintang (star) dan sapi perah (cash cow). (4) Tugas organisasi selanjutnya adalah menentukan sasaran, strategi dan anggaran yang dialokasikan kepada masing-masing unit bisnis. (5) Mengidentifikasi peluang dari eksternal organisasi guna pemanfaatan SI/TI yang dapat meningkatkan. Cara mengidentifikasi peluang tersebut dengan menggunakan analisis Porter's Five Force.

\section{Analisis Lingkungan Internal Bisnis Organisasi}

Tujuan dari kegiatan ini adalah untuk mengetahui lingkungan bisnis sebagai dasar mengidentifikasi peluangpeluang SI, menentukan strategi SI, dan keunggulan bersaing organisasi.

\section{Mengetahui dan Memahami Rencana Bisnis Organisasi}

Untuk mengetahui rencana bisnis organisasi dapat dilakukan dengan menggunakan beberapa analisis antara lain Analisis SWOT, Analisis Value Chain.

\section{Analisis SWOT}

Kegiatan analisis SWOT berupa identifikasi kekuatan, kelemahan, peluang, dan ancaman yang paling mendasar disusun dalam bentuk matriks. Dimana kekuatan dan kelemahan adalah merupakan faktor internal dan peluang dan ancaman merupakan faktor eksternal.

Matriks tersebut menggambarkan dampak kekuatan dan kelemahan secara keseluruhan terhadap peluang dan ancaman yang ada atau sebaliknya, dampak kekuatan terhadap ancaman serta peluang atau sebaliknya, dan dampak kelemahan terhadap peluang serta peluang atau sebaliknya.

\section{Pembuatan Strategi Berdasarkan SWOT}

Setelah mengidentifikasi beberapa Kekuatan, Kelemahan, Peluang dan Ancaman, kemudian dilakukan pemetaan antara lain: (1) kekuatan (strength) $><$ peluang (opportunity) menghasilkan Strategi SO, strategi yang menggunakan kekuatan untuk memanfaatkan peluang; (2) kekuatan (strength) $><$ ancaman (threat) menghasilkan Strategi ST, strategi yang menggunakan kekuatan guna menghindar dari ancaman; (3) kelemahan (weakness) $><$ peluang (opportunity), menghasilkan Strategi WO, strategi yang memanfaatkan peluang yang ada untuk mengatasi kelemahan; (4) kelemahan (weakness) $><$ ancaman (threat), menghasilkan Strategi WT, strategi yang memanfaatkan peluang yang ada guna meminimalkan kelemahan dan menghindari ancaman.

\section{Analisis Value Chain}

Analisis value chain terdiri dari: identifikasi aktifitas utama dan aktifitas pendukung perguruan tinggi; dan lakukan analisis terhadap proses-proses dalam aktifitas utama dan proses-proses aktifitas pendukung yang kinerjanya tidak efisien dan memerlukan biaya yang besar, dan kemudian mengapa hal tersebut terjadi, proses-proses tersebut dapat disederhanakan atau diubah pola kerjanya? Apakah SI/TI dapat berperan dan membantu kegiatan tersebut?

Jika sudah ada lakukan identifikasi dan jika belum lakukan analisis kebutuhan SI terhadap masalah tersebut dan sebutkan dampak jika persoalan tersebut dan hitung berapa besar keuntungan atau laba yang diperoleh jika memanfaatkan $\mathrm{SI} / \mathrm{TI}$.

\section{Mengetahui Kebutuhan Informasi Dalam Proses Bisnis Organisasi}

Untuk mengetahui kebutuhan informasi bisnis organisasi perlu dibuat ringkasan kebutuhan informasi yang berisi atau bersumber dari (1) aktivitas setiap bagian dalam value chain yang perlu diperbaiki atau dioptimalkan melalui pemanfaatan informasi internal organisasi yang lancar; (2) strategis bersaing dan memenangkan persaingan, misal meningkatkan daya tawar terhadap pemasok dan pembeli, dapat meninggikan peluang masuknya pemain baru, berhenti dari persaingan, atau berkonsentrasi di segmen pasar tertentu; (3) kemungkinan perubahan strategi dan proses bisnis.

\section{Analisis Lingkungan Eksternal SI/TI Organisasi}

Analisis lingkungan eksternal SI/TI berguna untuk mengetahui perkembangan teknologi dalam organisasi dan menelaah teknologi tersebut guna dimanfaatkan dalam mendukung strategis bisnisnya di saat yang akan datang. Ada beberapa proses yang dilakukan guna mengetahui perkembangan teknologi dalam organisasi yaitu: (1) mengetahui perkembangan teknologi dalam organisasi; (2) mengetahui peluang keunggulan kompetitif terhadap pesaing.

Proses-proses ini lebih detail dijelaskan pada subbab berikut ini, yaitu: (1) mengetahui perkembangan teknologi dalam organisasi, untuk mengetahui perkembangan teknologi dalam mendukung organisasi (perguruan tinggi), dilakukan pendataan teknologi yang digunakan saat ini, kemudian dikelompokkan berdasarkan fungsi bisnis organisasi, mencari dampak positif atau dampak negatif dalam menggunakan SI/ TI tersebut serta mengevaluasi dengan sumber daya SI/TI yang ada. Hasil dari proses ini didapatkan daftar SI/TI yang digunakan saat ini dalam organisasi. (2) mengetahui peluang keunggulan kompetitif terhadap pesaing.

Konsep strategis option generator dapat digunakan dalam melakukan analisis peluang keunggulan kompetitif pada pemanfaatan teknologi yang ada. Konsep tersebut dilakukan secara bottom up, yaitu: (1) tentukan teknologi/ teknik/prosedur yang akan digunakan; (2) tentukan arah penggunaannya, yakni manajemen harus menyediakan saja atau juga membantu penggunaannya; (3) tentukan modus strategi penggunaan secara ofensif atau defensif; (4) berdasarkan jawaban pertanyaan (2) dan (3) tersebut maka kesimpulan keunggulan kompetitif yang mungkin didapatkan, apakah diferensiasi, biaya, inovasi, pertumbuhan, atau aliansi?; (5) tentukan pengguna akhirnya; (6) membuat prioritas usulan pemanfaatan. Hasil dari analisis tersebut berupa daftar rincian keunggulan kompetitif teknologi dan daftar prioritas pemanfaatan teknologi

\section{Analisis Lingkungan Internal SI/TI Organisasi}

Analisis lingkungan internal SI/TI mencakup seluruh sumber daya SI/TI dalam organisasi. Sumber daya yang dimaksud adalah seluruh sistem, teknologi, dan manajemen informasi yang ada dan dimanfaatkan oleh organisasi untuk keperluan bisnis dan teknis. Analisis lingkungan bisnis ini merupakan kegiatan untuk mengetahui posisi, keadaan dan kekuatan SI/TI organisasi. Ketiga hal tersebut menjadi patokan dan pertimbangan melakukan renstra guna pemanfaatan SI/ TI bagi organisasi di saat mendatang.

\section{Tahap 3: Menentukan Target Bagi SI/TI}

Kegiatan tahap ini bertujuan untuk mengidentifikasi masalah dan peluang pemanfaatan SI/TI yang terjadi dalam memenuhi kebutuhan strategi bisnis baik secara internal maupun eksternal, menganalisis gap kebutuhan informasi, membuat landasan kebijakan strategi SI/TI terhadap organisasi secara keseluruhan, membuat strategi SI/TI. 
Masukan yang diperlukan pada tahap ini adalah identifikasi kebutuhan bisnis organisasi mendatang, identifikasi peluang pemanfaatan SI/TI, dan pemenuhan kebutuhan SI/TI saat ini. Adapun proses-proses yang dilakukan dalam tahap ini adalah sebagai berikut :

\section{Identifikasi masalah dan solusi internal}

Identifikasi masalah dan solusi internal yaitu: (1) mengetahui permasalahan bisnis yang dihadapi organisasi dan mencari solusi SI/TI-nya; (2) mengumpulkan informasi mengenai seluruh aplikasi, file-file spreadsheet lokal yang digunakan oleh setiap bagian dalam organisasi; (3) mengklasifikasi setiap aplikasi ke dalam segmen portofolio aplikasi, setelah di klarifikasikan berdasarkan segmen portofolio diatas, kemudian dipetakan ke kuadran portofolio seperti pada Tabel 1; (4) mengidentifikasi cakupan dan konstribusi aplikasi pada organisasi (fungsi-fungsi bisnis mana yang di layani), termasuk kemungkinan peningkatan kualitas layanan aplikasi dengan melakukan interview terhadap senior manager divisi yang bersangkutan; (5) mengumpulkan informasi mengenai kebijakan-kebijakan dan strategi SI/TI sebelumnya; (6) mengidentifikasi cakupan dan konstribusi aplikasi pada organisasi (fungsi-fungsi bisnis mana yang di layani), termasuk kemungkinan peningkatan kualitas layanan aplikasi dengan melakukan interview terhadap senior manager divisi yang bersangkutan; (7) mengumpulkan informasi mengenai kebijakan-kebijakan dan strategi SI TI sebelumnya; (8) mengumpulkan informasi mengenai organisasi dan proses-proses SI/TI termasuk: fungsi, ukuran, struktur dan hubungan departemen SI/TI maupun individuindividu tertentu, pengelolaan penyediaan sumber daya SI/TI, stuktur Tata kelola SI/TI, termasuk proses-proses pengambilan keputusan dan steering committe yang ada, dan bagaimana anggaran investasi SI/TI disiapkan.

Tabel 1 Hasil Klasifikasi SI saat ini

\begin{tabular}{|c|c|}
\hline High Potensial & Strategic \\
\hline 1. & 1. \\
\hline 2. & 2. \\
\hline 3. & 3. \\
\hline Support & Factory (Key Operation) \\
\hline 1. & 1. \\
\hline 2. & 2. \\
\hline 3. & 3. \\
\hline
\end{tabular}

\section{Identifikasi Peluang Bisnis dari Eksternal Organisasi}

Kegiatan untuk menganalisis dan menelaah temuan peluang bisnis dan ekternal organisasi guna dimanfaatkan bagi keunggulan kompetitif organisasi, yaitu (1) gunakan hasil analisis kompetitif lima kekuatan porter; (2) cari kekuatan pemasok, pesaing, dan konsumen; (3) hubungkan pengaruhnya terhadap organisasi dengan cara identifikasi komponen yang kritis dari lingkungan eksternal dengan komponen yang berpengaruh terhadap persaingan dalam organisasi. Dapat pula mendasarkan hasilnya dari pengaruh lingkungan eksternal pada segmen bisnis. Setelah itu buat SWOT yang sesuai dengan hasil identifikasi; (4) setelah itu lakukan identifikasi keterkaitan utama organisasi dengan lingkungan eksternal. Hal itu dilakukan dengan cara: mencari kekuatan organisasi, memeriksa komponen value chain yang berhubungan dengan lingkungan eksternal, mencari peluang SI yang ada di SWOT dan value chain, dan kebijakan internal organisasi yang mempengaruhi industri; (5) memperoleh peluang SI berdasarkan analisis value chain. Caranya mengidentifikasi hal tersebut dengan berdasarkan aktifitas value proses bisnis, menentukan prioritas yang tertinggi pada hasil identifikasi. Hasil dari kegiatan ini adalah identifikasi peluang pemanfaatan SI pada pemasok, konsumen, pesaing, pemain baru, pemain pengganti, Komponen Value Chain dan Analisis SWOTnya.

\section{Analisis Gap Kebutuhan Informasi}

Analisis Gap bertujuan untuk mencari pemenuhan informasi bisnis mendatang berdasarkan kebutuhan informasi bisnis mendatang dan kemampuan sumber daya SI/TI organisasi saat ini. Kebutuhan informasi yang belum dapat dipenuhi saat ini ataupun yang perlu ditingkatkan kualitasnya merupakan target utama bagi kegiatan Perencanaan Strategis SI/TI untuk dicarikan pemenuhannya. Adapun proses-proses yang dilakukan dalam tahap ini adalah sebagai berikut: menentukan peluang keunggulan kompetitif dari strategi SI/TI, menentukan kebijakan/perangkat untuk menyeleksi strategi SI/TI, dan menentukan kebijakan investasi pada bidang SI/TI.

\section{Membuat Strategi SI/TI}

Tujuan kegiatan ini adalah untuk menindaklanjuti temuan pemenuhan kebutuhan informasi, yakni dengan cara membuat strategi, penentuan pemanfaatan SI/TI. Hasil akhirnya adalah usulan sistem, teknologi, dan manajemen informasi yang diperlukan di tahap selanjutnya.

\section{Tahap 4: Menentukan Strategi SI/TI}

Tahap ini dimaksudkan untuk memilih terget aplikasi yang akan dijadikan solusi strategis SI/TI. Pemilihan tersebut dilakukan dengan memberi rangking/peringkat terhadap target aplikasi. Peringkat tersebut disusun berdasarkan kompilasi kriteria value bisnis, teknis, dan risiko. Terget aplikasi dengan peringkat tinggi akan dijadikan solusi strategis SI/TI. Strategis yang dihasilkan adalah Strategi Manajemen SI/TI, Strategi Bisnis SI/TI, dan Strategi SI/TI.

\section{Tahap-5 : Rencana Implementasi}

Tahap ini merupakan tahap terakhir dari lima tahapan yang bertujuan untuk membuat rencana dan jadwal kerja guna mengimplementasikan solusi strategis SI/TI, yaitu: (1) membuat rencana pendukung strategi SI/TI, membuat rencana pendukungan strategi SI/TI bertujuan untuk mencari detail kegiatan dan kebutuhan dari solusi strategis guna sebagai masukan data pembuatan jadwal, dan rencana kerja tahap berikutnya; (2) pembuatan jadwal waktu kerja, bertujuan untuk membuat jadwal implementasi solusi strategis SI/ TI secara detail perkegiatan. Jadwal tersebut dibuat sesuai dengan satuan waktu pelaksanaan projek yang didefinisikan sebelumnya; (3) pembuatan rencana pelaksanaan, bertujuan untuk merinci setiap kegiatan pelaksanaan solusi strategis SI/ TI secara detail. Selain itu kegiatan ini melengkapi jadwal kerja yang telah terbentuk dengan asumsi ideal pelaksanaan projek, berupa keadaan lingkungan eksternal dan internal bisnis dan SI/TI organisasi, sumber daya organisasi, biaya, dan jadwal kerja pendukung.

\section{Rangkuman dari Usulan Kerangka Kerja Perencanaan Strategis SI/TI}

Pembuatan usulan kerangka kerja rencana strategis SI/TI yang digunakan pada sebuah perguruan tinggi (STMIK XYZ) bertujuan untuk meningkatkan value bisnis dan menciptakan keunggulan kompetitif perguruan tinggi tersebut.

Usulan kerangka kerja perencanaan strategis SI/TI, pihak STMIK XYZ dapat mengetahui faktor-faktor penting 
yang diperlukan dalam mengembangkan suata sistem informasi yang selaras dengan Rencana strategis STMIK XYZ. Faktor-faktor penting tersebut dapat dilihat dari hasil analisis SWOT, PEST, BCG Matriks, Porter, CSF dan KPI, serta value chain yang dilakukan terhadap strategi dan model bisnis STMIK XYZ.

\section{PENUTUP}

Berdasarkan hasil analisisyang telah sebelumnya, maka dapat diambil beberapa simpulan bahwa hasil dari penelitian yang dilakukan adalah sebuah kerangka kerja rencana strategis SI/TI yang dapat digunakan pada sebuah perguruan tinggi (STMIK XYZ) serta sesuai dengan tujuan penelitian. Usulan kerangka kerja perencanaan strategis SI/TI, pihak STMIK XYZ dapat mengetahui faktor-faktor penting yang diperlukan dalam mengembangkan suatu sistem informasi yang selaras dengan Rencana strategis STMIK XYZ. Faktorfaktor penting tersebut dapat dilihat dari hasil analisis SWOT, PEST, BCG Matriks, Porter, CSF dan KPI, serta value chain yang dilakukan terhadap strategi dan model bisnis STMIK XYZ. Kesimpulan yang didapatkan dalam hasil penelitian ini ádalah kerangka kerja perancangan rencana strategis SI/ TI yang usulkan dapat diimplementasikan dan digunakan sebagai alat dalam merencanakan rencana strategis SI/TI STMIK XYZ pada masa yang akan datang.

\section{DAFTAR PUSTAKA}

Earl, M. J. (1996). Management Strategies for Information Technology (1st ed.). Prentice Hall.

Pant, S., \& Hsu, C. (1995). Strategic Information Systems Planning: A Review., 1995 Information Resources Management Association International Conference, May 21-24, Atlanta, Georgia .

Porter, M. E. (1985). Competitive Advantage: Creating and Sustaining Superior Performance. The Free Press.

Ward, J., \& Preppar, J. (2002). Strategic Planning for Information System (2nd ed.). John Wiley \& Sons. 